The assistance of Pharmacia A.B., Uppsala, Sweden, and the co-operation of the staff of the department of thoracic surgery, Academic Hospital, Uppsala, Sweden, are gratefully acknowledged. Our thanks are also due to $\mathrm{Mr}$. D. Hall for statistical advice.

\section{REFERENCES}

Akbarian M., Austen, W. G., Yurchak, P. M., and Scannell, J. G. (1968), Circulation, 37, 826.

Ashmore, P. G., Svitek, V., and Ambrose, P. (1968). Fournal of Thoracic and Cardiovascular Surgery, 55, 691 .

Bennett, P. N. (1967). Fournal of Clinical Pathology, 20, 708.

Bernstein, E. F., Indeglia, R. A., Shea, M. A., and Varco, R. L. (1967). Circulation, 35, Suppl. No. 1, p. 226

Brecher, G., and Cronkite, E. P. (1950). Fournal of Applied Physiology, 3, 365 .

Bygdeman, S., Eliasson, R., and Johnson, S.-R. (1966). Lancet, 1, 1301. Cooley, D. A., Nelson, T. G., Beall, A. C., jun., and DeBakey, M. E. (1964). Diseases of the Çhest, 46, 339 .

Crafoord, C., Norberg, B., and Senning, \&. (1957). Acta Chirurgica Scandinavica, 112, 220 .

DeWall, R. A., Long, D. M., Gemmill, S. J., and Lillehei, C. W. (1959). fournal of Thoracic Surgery, 37,325.

Dhall, D. P., and Matheson, N. A. (1969). Circulation Research, 3, 155.

Dhall, D. P., and Matheson, N. A. (1969). Circulation Research, 3, 155.
Duvoisin, G. E., Brandenburg, R. O., and McGoon, D. C. (1967). Circulation, 35, Suppl. No. 1, p. 70 .
Effler, D. B., Favaloro, R., and Groves, L. K. (1965). Annals of Thoracic

Surgery, 1, 4.
Ellis, L. B., Harken, D. E., and Black, H. (1959). Circulation, 19, 803. Emmons, P. R., and Mitchell, J. R. A. (1965). Lancet, 1, 71 .

Gollub, S., and Ulin, A. W. (1962). fournal of Laboratory and Clinical Medicine, 59, 430 .

Ham, J. M., and Slack, W. W. (1967). British fournal of Surgery, 54, 385.

Hampton, J. R., and Mitchell, J. R. A. (1966). British Medical fournal, 1, 1078 .

Hellem, A. J. (1960). Scandinavian Fournal of Clinical and Laboratory Investigation, 12, Suppl. p. 51.

Herr, R., Starr. A., McCord, C. W., and Wood, J. A. (1965). Annals of Thoracic Surgery, 1, 403.

Kendall, A. G., and Lowenstein, L. (1962). Canadian Medical Association fournal, 87, 786.

Loogen, Fournal, Seipel, L. (1967). Deutsche medizinische Wochenschrift, 92, 1 .,

Mirkovitch, V., Akutsu, T., and Kolff, W. J. (1960). Physiologist, 3, 114.

Murphy, E. A., Mustard, J. F., Rowsell, H. G., and Downie, H. G. (1963). Fournal of Laboratory and Clinical Medicine, 61, 935.

Olesen, K. H. (1955). Mitral Stenosis: A Follow-up of 351 Patients. Copenhagen, Munksgaard.

Sharp, A. A., Excell, B., Salzman, E., and Thorup, O. (1961). In Thrombosis and Anticoagulant Therapy, edited by W. Walker, p. 88. Edinburgh, Livingstone.

Wright, H. P. (1942). Fournal of Pathology and Bacteriology, 54, 461.

Yeh, T. J., Anabtawi, I. N., Cornett, V. E., and Ellison, R. G. (1967). Circulation, 35, Suppl. No. 1, p. 77.

\title{
Biologically Active Cortisol in Plasma of Oestrogen-treated and Normal Subjects
}

\author{
C. W. BURKE,* M.A., M.R.C.P.
}

\begin{abstract}
Summary: Biologically active (non-protein-bound) $S$ cortisol levels in the plasma of 13 women taking oral contraceptives and of 67 normal subjects were compared, using a new method-steady-state gel filtration. Both total and unbound cortisol levels in the 67 normal subjects showed a skew distribution, which was roughly lognormal.

Unbound cortisol levels in 11 of the oestrogen-treated women were in the normal range, but the median value was significantly increased in this group. Total plasma cortisol levels in the oestrogen-treated group were, as expected, increased threefold, and all were outside the normal range.
\end{abstract}

\section{Introduction}

The biological activity of the cortisol (hydrocortisone) circulating in the bloodstream is exerted by the $5-10 \%$ which is not bound to protein (Slaunwhite et al., 1962; Matsui and Plager, 1966). The total plasma cortisol level in man is increased by administration of oestrogen, due to a threefold-increase in the plasma concentration of the major cortisol-binding protein, corticosteroid-binding globulin (Sandberg and Slaunwhite, 1959; Mills et al., 1960; Doe et al., 1964). But it is less certain whether unbound, biologically active cortisol levels in plasma are also increased by the administration of oestrogen.

It would be predicted that unbound cortisol levels would be normal in oestrogen-treated subjects, for they show no clinical

* Senior Registrar, Department of Medicine, Royal Postgraduate Medical School, London W.12. evidence of cortisol excess ; moreover, their urinary cortisol excretion is within the normal range (Sandberg et al., 1967). Indeed, Mills et al. (1960) found that non-protein-bound cortisol levels "remained the same" during the administration of oestrogen. Others, however, have found increased unbound levels in oestrogen-treated subjects ; for example, a mean value of $4.2 \mu \mathrm{g} . / 100 \mathrm{ml}$. compared with normal mean of 0.9 $\mu \mathrm{g} . / 100 \mathrm{ml}$. (Doe et al., 1960); a mean value of $4.4 \mu \mathrm{g} . /$ $100 \mathrm{ml}$. compared with normal mean of $1.25 \mu \mathrm{g} . / 100 \mathrm{ml}$. (Plager et al., 1964 ; a mean value of $2.6 \mu \mathrm{g} . / 100 \mathrm{ml}$. compared with normal mean of $1.0 \mu \mathrm{g} . / 100 \mathrm{ml}$. (Murray, 1967). These raised values are surprising in view of the diminished production of cortisol found in oestrogen-treated subjects (Peterson et al., 1960 ; Layne et al., 1962). Some of these differences may be exaggerated by the technical difficulties in measuring unbound cortisol.

This paper compares values for unbound cortisol in normal and oestrogen-treated subjects, which were obtained by a new method, steady-state gel filtration. This method, which possesses high precision, does not appear to have been applied to measuring hormone-binding phenomena in the blood of man, and it would seem useful to apply it to cortisol-binding in oestrogen-treated subjects.

\section{Subjects and Methods}

Blood was drawn between 9.30 and 10 a.m. from 36 male and 31 female healthy clerical and medical staff, and from 13 women who had taken $0 \cdot 1 \mathrm{mg}$. of mestranol, combined with a progestogen, in the form of various oral contraceptive tablets for at least two menstrual cycles. All subjects were 
aged 17 to 40 , and total plasma cortisol levels were outside the normal range in all the oestrogen-treated women.

Total plasma cortisol was measured in duplicate by a modification of the method of Murphy (1967) (competitive proteinbinding analysis). The details of the assay were similar to those previously given for measuring cortisol in urine in this laboratory (Beardwell et al., 1968), except that precision in the 0-10 ng. range was much improved by use of corticosteroidbinding globulin at greater dilution.

Unbound plasma cortisol was measured by steady-state gel filtration (Burke, 1969). The principle of this method is that $25 \mathrm{ml}$. of the test plasma is passed continuously into a Sephadex column at $37^{\circ} \mathrm{C}$. until a steady state is reached, when the cortisol-binding equilibria can be accurately observed in the presence of all plasma constituents at their proper concentrations and at body $p \mathrm{H}$ and temperature. The average deviation from the mean of 14 replicate estimates of unbound cortisol by this method was $\pm 4 \%$.

\section{Results}

Normal Subjects.-There is trivial difference between the sexes in either unbound or total cortisol levels, as expected (see Table). The values for both levels showed a skewed (nonGaussian) distribution in the 67 normal subjects (Fig. 1). They were compatible with a log-normal distribution ( $\chi^{2}$ test for goodness of fit to normal distribution, $P=0 \cdot 1-0 \cdot 2$ for absolute values, $0.5-0.6$ for $\log _{10}$ values). In such a case it seems more appropriate when comparing groups to compare means derived from $\log _{10}$ values (Gaddum, 1945).

Unbound and Total Cortisol in Plasma of Normal and Oestrogen-treated Subjects

\begin{tabular}{|c|c|c|c|c|c|}
\hline \multirow{2}{*}{\multicolumn{2}{|c|}{ Group }} & \multicolumn{2}{|c|}{$\begin{array}{l}\text { Unbound Cortisol } \\
(\mu \mathrm{g} . / 100 \mathrm{ml} .)\end{array}$} & \multicolumn{2}{|c|}{$\begin{array}{l}\text { Total Cortisol } \\
(\mu \mathrm{g} / .100 \mathrm{ml} .)\end{array}$} \\
\hline & & Mean (S.D.*) & Range & Mean (S.D. *) & Range \\
\hline $\begin{array}{l}36 \text { normal males } \\
31 \text { normal females } \\
67 \text { males + females } \\
13 \text { oestrogen-treated }\end{array}$ & $\begin{array}{l}\because \\
\therefore\end{array}$ & $\begin{array}{l}0.68( \pm 0.47) \\
0.66( \pm 0.34) \\
0.67( \pm 0.41)\end{array}$ & $\begin{array}{l}0 \cdot 1-1 \cdot 8 \\
0 \cdot 1-1 \cdot 4 \\
0 \cdot 1-1 \cdot 8\end{array}$ & $\begin{array}{l}10 \cdot 8( \pm 3.0) \\
12 \cdot 0( \pm 3 \cdot 7) \\
11 \cdot 3( \pm 3 \cdot 3)\end{array}$ & $\begin{array}{l}5 \cdot 5-16 \cdot 0 \\
4 \cdot 0-20 \cdot 4 \\
4 \cdot 0-20 \cdot 4\end{array}$ \\
\hline females $\quad$. & .. & $1.07( \pm 0.37)$ & $0.5-1.8$ & $33 \cdot 7( \pm 7 \cdot 8)$ & $21 \cdot 5-44 \cdot 0$ \\
\hline
\end{tabular}

* Calculated as if data were normally distributed-see text.
Oestrogen-treated Subjects.-The total plasma cortisol levels in the oestrogen-treated women showed the expected threefold increase, and none was in the normal range (see Table).

In contrast, the unbound cortisol levels were all within the normal range for men and women combined (Fig. 2). Only two values were outside the normal female range. There is some rise of the mean value; however, in view of the skew distribution referred to above, the data have been replotted on a log scale in Fig. 3. The increase in the $\log _{10}$ mean for the oestrogen-treated group is not large, though it is statistically significant $(t=3.11, \mathrm{P}=0.003$ for 42 degrees of freedom).

\section{Discussion}

It was pointed out above that normal plasma unbound cortisol levels would be expected in oestrogen-treated subjects, their high total cortisol levels being due to raised corticosteroidbinding globulin concentration. The present findings do not warrant drawing any conclusions from the increase in mean and median unbound cortisol in the oestrogen-treated group, since 11 out of the 13 values are within the normal range. The inorease is unlikely to be due to oestrogen interference with the cortisol assay, for Murphy (1967) found no such interference by amounts of some oestrogens far higher than those likely to be encountered in plasma.

The present finding that mean unbound cortisol levels are increased by only $50 \%$ in oestrogen-treated subjects contrasts with some previous reports, but the differences may be partly due to methodological errors. For example, the non-equilibrium electrophoresis method used by Doe et al. (1960) is subject to dissociation of steroid-protein complexes, resulting in higher unbound values, and in some of the ultrafiltration experiments of Plager et al. (1964) there seems to have been a considerable change of cortisol concentration which may have affected the results. The method used here has the advantages of practical simplicity, high reproducibility, and preservation of true equilibrium. The results obtained are closer to the results of Murray (1967), who used carefully controlled ultrafiltration and chromatography to measure the unbound cortisol.

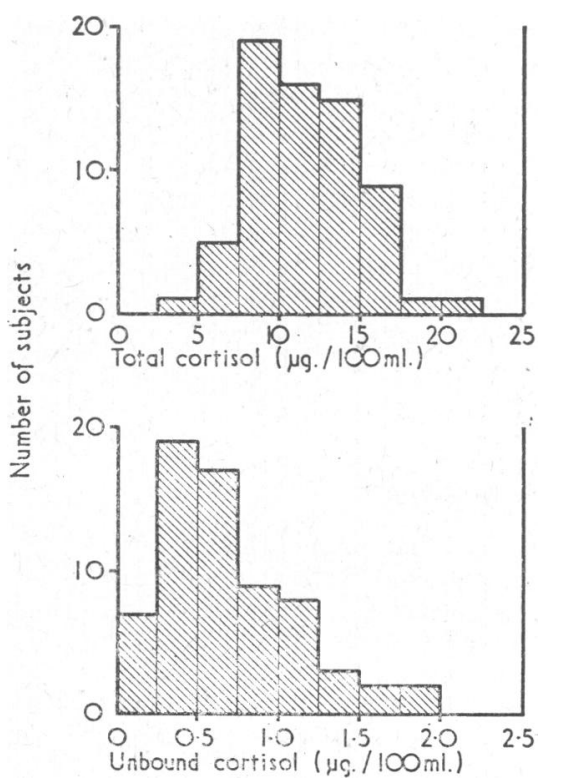

FIG. 1

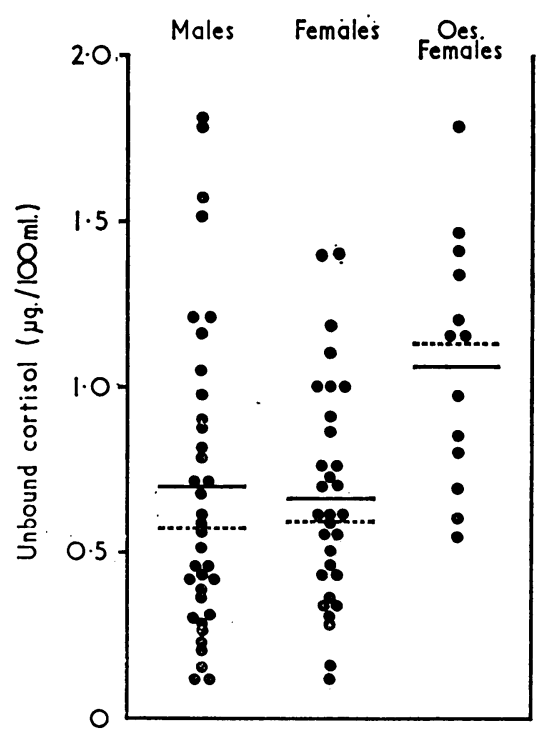

FIG. 2

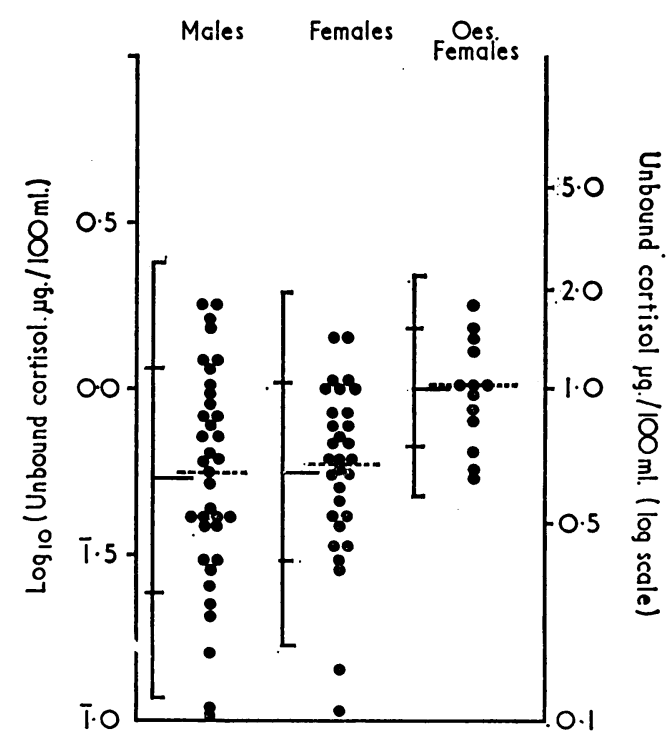

FIG. 3

FIG. 1.-Distribution of cortisol in 67 normal subjects. The skewed distribution is clearly seen, both for total plasma cortisol (top) and unbound plasma cortisol (bottom). Note different scales for comparison. FIG. 2.-Unbound cortisol in plasma of normal and oestrogen-treated subjects. The values found in 36 normal males, 31 normal females, and 13 oestrogen-treated females (OES) are shown separately. The bars denote means, and the dotted lines indicate median values. FIG. 3.- - $\log _{10}$ values for unbound cortisol in plasma. The same values as shown in Fig. 2 are plotted on a log scale, to show the size of the difference be tween the normal and oestrogen-treated (OES) groups. The vertical bars carry mean \pm 2 S.D., and the dotted lines indicate the medians. 
The period of oestrogen treatment used by Mills et al. (1960) is too short to allow comparison.

The dose of oestrogen used in the present work was sufficient to cause an increase in corticosteroid-binding globulin concentration, as judged by total cortisol levels. This dose is equivalent to slightly less diethylstilboestrol than that causing maximum corticosteroid-binding globulin increment (Doe et al., 1967). Therefore oral contraceptives may not cause so great an increase in unbound cortisol as, for example, the high doses of oestrogen used in the treatment of prostatic carcinoma.

The skewed distribution of both total and unbound cortisol in normal subjects explains the similar distribution of urinary cortisol found by Cope and Black (1959). Many plasma constituents are distributed in this way (Wootton, 1964), and the distribution must be taken into account when calculating the mean of a range of values (Gaddum, 1945). This also may be a factor in the disparity of some previous estimates of unbound cortisol.

I am indebted to Professor T. Russell Fraser and to Dr. C. L. Cope for both support and criticism. This work was carried out during the tenure of a Medical Research Counoil grant.
REFERENCES

Beardwell, C. G., Burke, C. W., and Cope, C. L. (1968). Fournal of Endocrinology, 42, 79.

Burke, C. W. (1969). Biochimica et Biophysica Acta, 176, 403

Cope, C. L., and Black, E. G. (1959). British Medical fournal, 2, 1117.

Doe, R. P., Fernandez, R., and Seal, U. S. (1964). Fournal of Clinical Endocrinology and Metabolism, 24, 1029.

Doe, R. P., Mellinger, G. T., Swaim, W. R., and Seal, U. S. (1967). Fournal of Clinical Endocrinology and Metabolism, 27, 1081.

Doe, R. P., Zinneman, H. H., Flink, E. B., and Ulstrom R. A. (1960). fournal of Clinical Endocrinology and Metabolism, 20, 1484.

Gaddum, J. H. (1945). Nature, 156, 463.

Layne, D. S., Meyer, C. J., Vaishwanar, P. S., and Pincus, G. (1962). fournal of Clinical Endocrinology and Metabolism, 22, 107.

Matsui, N., and Plager, J. E. (1966). Endocrinology, 78, 1159.

Mills, I. H., Schedl, H. P., Chen, P. S., and Bartter, F. C. (1960). fournal of Clinical Endocrinology and Metabolism, 20, 515

Murphy, B. E. P. (1967). Fournal of Clinical Endocrinology and Metabolism, 27, 973 .

Murray, D. (1967). Fournal of Endocrinology, 39, 571.

Peterson, R. E., Nokes, G., Chen, P. S., and Black, R. L. (1960). Fournal of Clinical Endocrinology and Metabolism, 20, 495 .

Plager, J. E., Schmidt, K. G., and Staubitz, W. J. (1964). Fournal of Clinical Investigation, 43, 1066.

Sandberg, A. A., Rosenthal, H., and Slaunwhite, W. R. (1967). Proceedings of Second International Congress on Hormonal Steroids, edited by L. Martini, p. 707. Amsterdam, Excerpta Medica Foundation.

Sandberg, A. A., and Slaunwhite, W. R. (1959). Fournal of Clinical Investigation, 38, 1290.

Slaunwhite, W. R., Lockie, G. N., Back, N., and Sandberg, A. A. (1962). Science, 135, 1062 .

Wootton, I. D. P. (1964). In Microanalysis in Medical Biochemistry, 4th ed., edited by I. D. P. Wootton, p. 3. London, Churchill.

\title{
Studies in a Patient with Acute Leukaemia after Lysergide Treatment
}

\author{
O. MARGARET GARSON,* M.B., B.S.; MERYL K. ROBSON, $\dagger$ M.SC.
}

\begin{abstract}
Cummary : The second case of acute leukaemia develop$\checkmark$ ing after administration of lysergide is reported. The unusual bone-marrow chromosome pattern and the presence of large cells containing multiple micronucleoli suggest that this association may be causal.
\end{abstract}

\section{Introduction}

Cohen et al. (1967a) first reported that the addition of lysergic acid diethylamide (lysergide) to cultured human leucocytes resulted in a noticeable increase in chromosomal abnormalities. They also found similar abnormalities in the lymphocytes of a patient treated extensively with the drug. Since that time there have been a number of reports confirming these observations (Irwin and Egozcue, 1967 ; Cohen et al., 1967b ; Jarvik and Kato, 1968 ; Nielsen et al., 1968 ; Hungerford et al., 1968), and only two reports (Loughman et al., 1967 ; Sato and Pergament, 1968) where no abnormalities were found.

Data are accumulating on the occurrence of congenitally malformed children born to parents who had taken lysergide during pregnancy. (Zellweger et al., 1967 ; Hecht et al., 1968). Egozcue et al. (1968) found a " $\mathrm{Ph}^{1}$-like" chromosome in three users of the drug and in the progeny of four others, and Grossbard et al. (1968) reported the case of a patient with acute leukaemia and a " $\mathrm{Ph}^{1}$-like" chromosome, who had been

* Research Fellow.

t Research Assistant.

University of Melbourne Department of Medicine, St. Vincent's Hospital, Melbourne, 3065, Australia. taking lysergide. Hence there is probably sufficient evidence to suggest a relationship between lysergide and chromosome abnormalities. The occurrence of these chromosome abnormalities may also imply a possible leukaemogenic effect, similar to the situation that exists in Bloom's syndrome (Sawitsky et al., 1966) and Fanconi's anaemia (Bloom et al., 1966). While the significance of these abnormalities is uncertain, it is important to report any case in which lysergide administration has been followed by the occurrence of either leukaemia or congenital malformation. This communication reports the cytogenetic studies performed on a patient who had been given injections of lysergide for a depressive state and who subsequently developed acute lymphoblastic leukaemia.

\section{Case Report}

The patient, a man aged 23, first presented in October 1968 with a 12-month history of increasing tiredness and a more recent onset of pallor. Two months before admission he had a severe "influenza-like illness" followed by low back pain. One week before admission he developed bleeding gums and a petechial rash over both legs. He was a tall, pale young man with marked sternal tenderness; the spleen was palpable $7 \mathrm{~cm}$. and the liver $5 \mathrm{~cm}$. below left and night costal margins, respectively. There was slight enlargement of the inguinal lymph nodes. On admission his haemoglobin was $11.2 \mathrm{~g} . / 100 \mathrm{ml}$., the white cell count $4,000 /$ cu. mm., with $25 \%$ blast cells, and a platelet count $12,000 /$ cu. $\mathrm{mm}$. Bone-marrow aspiration produced a hypercellular marrow showing $90 \%$ blast cells, thought to be lymphoblastic in type. Treatment was begun with prednisolone $60 \mathrm{mg}$. daily and three 